\title{
Gram per Milliliter per Milligram per Meter Squared per Day
}

National Cancer Institute

\section{Source}

National Cancer Institute. Gram per Milliliter per Milligram per Meter Squared per Day. NCI Thesaurus. Code C119355.

A unit of concentration equal to grams per milliliter, divided by milligrams per meter squared per day. 